Original Article

\title{
Phylogenetic status and diet of red fox (Vulpes vulpes griffithii) inhabiting Ayubia National Park, Pakistan
}

\author{
Status filogenético e dieta da raposa-vermelha (Vulpes vulpes griffithii) que habita o \\ Parque Nacional de Ayubia, Paquistão
}

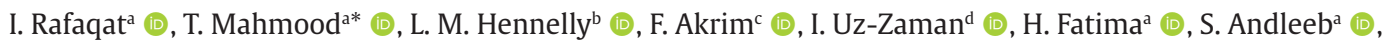
G. Muhammad ${\text { (D) Y. } \text { Abbas }^{\mathrm{f}} \text { (D), M. Farooq }}^{\mathrm{a}}$ (D), N. Munawar $^{\mathrm{a}}$ (D), M. R. Khan ${ }^{\mathrm{a}}$ (D), Abdul Hamida (D) and

M. A. Orakzai ${ }^{\text {(1) }}$

aPMAS Arid Agriculture University, Department of Wildlife Management, Rawalpindi, Pakistan

bUniversity of California, Veterinary Genetics Lab, Mammalian Ecology and Conservation Unit, Davis, CA, USA

University of Kotli Azad Jammu \& Kashmir, Department of Zoology, Azad Jammu and Kashmir, Pakistan

${ }^{\mathrm{d} D i v i s i o n a l ~ F o r e s t ~ O f f i c e r ~(D F O) ~ W i l d l i f e, ~ G a l l i a t ~ D i v i s i o n, ~ A b b o t t a b a d, ~ P a k i s t a n ~}$

'Baltistan Wildlife Conservation and Development Organization, Skardu, Pakistan

fDirectorate of the Central Karakoram National Park, Skardu, Pakistan

sWildlife Department, Project Director National Parks, Khyber Pakhtunkhwa, Peshawar, Pakistan

\begin{abstract}
The red fox (Vulpes vulpes) is a medium-sized carnivore that occurs in different regions of Pakistan, however, still lacks scientific data on its ecology and distribution. The current study investigated the phylogenetic status and diet of the red fox (V.v. griffithii) occurring in Ayubia National Park, Pakistan. Through camera trapping and molecular analysis, we confirmed the occurrence of red fox in the study area. Based on mitochondrial cytochrome B (304 bp) and limited sampling, nearly all red foxes of Ayubia National Park and surrounding Himalayan ranges fall within Holarctic maternal lineage, whereas red foxes found in plains of Pakistan are part of the basal Palearctic maternal lineage. Using 32 scats, we found that red fox diet comprises of $80 \%$ animal-based prey species (both wild and domestic) and 19\% plant matter. The wild animal prey species included Cape hare (Lepus capensis) and flying squirrel (Pteromyini sp.), which constituted $17 \%$ and $15 \%$ of diet, respectively. Red foxes infrequently consumed House mouse (Mus musculus), Himalayan Palm civet (Paguma larvata) and sheep (Ovis aries), each comprising around $6 \%$ to $9 \%$ of red fox diet. The fox species also scavenged on domestic donkey opportunistically. Based on our sampling, our study suggests that the red fox (V.v. griffithii) that occurs in Ayubia National Park and across the lesser Himalayan ranges belongs to Holarctic maternal lineage. The study also highlights consumption of plant seeds by red foxes, indicating it may play an important ecological role in seed dispersal in Ayubia National Park.
\end{abstract}

Keywords: phylogenetics, diet, distribution, Vulpes vulpes, red fox, scats.

\begin{abstract}
Resumo
A raposa-vermelha (Vulpes vulpes) é um carnívoro de médio porte que ocorre em diferentes regiões do Paquistão, porém ainda carece de dados científicos sobre sua ecologia e distribuição. O presente estudo investigou o status filogenético e a dieta da raposa-vermelha (V.v. griffithii) que ocorre no Parque Nacional de Ayubia, Paquistão. Por meio de armadilhas fotográficas e análises moleculares, confirmamos a ocorrência de raposa-vermelha na área de estudo. Com base no citocromo B mitocondrial (304 bp) e amostragem limitada, quase todas as raposas-vermelhas do Parque Nacional de Ayubia e áreas circundantes do Himalaia se enquadram na linhagem materna holártica, enquanto as raposas-vermelhas encontradas nas planícies do Paquistão fazem parte da linhagem materna basal paleártica. Usando 32 fezes, descobrimos que a dieta da raposa-vermelha compreende $80 \%$ de espécies de presas de origem animal (selvagens e domésticas) e 19\% de matéria vegetal. As espécies de presas de animais selvagens incluíram a lebre-do-cabo (Lepus capensis) e o esquilo-voador (Pteromyini sp.), que constituíram 17\% e 15\% da dieta, respectivamente. As raposas-vermelhas consumiam raramente ratos domésticos (Mus musculus), algas do Himalaia (Paguma larvata) e ovelhas (Ovis aries), cada um compreendendo cerca de $6 \%$ a $9 \%$ da dieta da raposa-vermelha. A espécie de raposa também se alimentava de burros domésticos de forma oportunista. Com base em nossa amostragem, nosso estudo sugere que a raposa-vermelha (V.v. griffithii) que ocorre no Parque Nacional de Ayubia e nas cordilheiras menores do Himalaia pertence à linhagem materna holártica. O estudo também destaca o consumo de sementes de plantas por raposas-vermelhas, indicando que pode desempenhar um papel ecológico importante na dispersão de sementes no Parque Nacional de Ayubia.
\end{abstract}

Palavras-chave: filogenética, dieta, distribuição, Vulpes vulpes, raposa-vermelha, fezes.

*e-mail: tariqjanjua75@uaar.edu.pk

Received: June 6, 2021 - Accepted: August 4, 2021

This is an Open Access article distributed under the terms of the Creative Commons Attribution License, which permits unrestricted use, distribution, and reproduction in any medium, provided the original work is properly cited. 


\section{Introduction}

The red fox (Vulpes vulpes) is the most widespread land mammal and occurs across five landmasses: Asia, Europe, Australia, northern Africa and North America (Ables, 1975). Consequently, the species shows a wide range of phenotypes and life history characteristics (MacDonald et al., 1999; Williams et al., 2004; Szuma, 2008), which is reflected in the high number of subspecies described. While extensively studied in North America and Europe, much less is known about the ecology and distribution of various red fox subspecies in Asia.

In Pakistan, the red fox occurs across the country with three sub-species currently recognized: Vulpes vulpes montana in the high-altitude region of the Karakoram and Hindu Kush ranges, V. v. griffithii (also called as Kashmir hill red fox) along the temperate mountainous regions, and V. v. pusilla in deserts and grasslands (Roberts, 1997). However, the distribution and genetic distinctiveness of these red fox subspecies is poorly understood. Generally, the red foxes in Africa, the Middle East, and South Asia fall within a distinct and basal maternal lineage, referred to as the Palearctic maternal lineage (Statham et al., 2014). It is estimated that the Palearctic maternal lineage diverged from other red fox clades before 400,000 years ago (Statham et al., 2014). In contrast, red fox populations found across Northern Eurasia form a recently diverged and shallow maternal lineage, with weak phylogeographic structuring corresponding to a population expansion event around 50,000 years ago (Kutschera et al., 2013; Statham et al., 2014). The extent and geographic region where the Holarctic and Palearctic maternal lineages come into contact remains unknown, as sampling in South and West Asia is sparse and past studies have relied upon museum specimens. Based on a few museum specimens, the desert-adapted white footed fox (V.v pusilla) of Pakistan falls within the basal Palearctic maternal lineage, while the red foxes within the high altitude of Northern Pakistan and Central Asia mostly fall within the Holarctic maternal lineage. Therefore, it has been suggested that a phylogeographic break for red foxes occurs in the Northern Pakistan and Central Asian region (Statham et al., 2014).

Based on morphology, the red fox sub-species (Kashmir hill red fox) is considered to be found along the Western Himalayan foothills and broadleaf forested montane regions of India, Afghanistan, and Pakistan. The subspecies is also reported from Balk, Badakhshan, Kabul, Faryab, Kanadahar, and Jowzjan provinces of Afghanistan (Blyth, 1854). In Pakistan, it is distributed in mountainous and inter mountainous valleys of Khyber Paktunkhwa, Azad Jammu \& Kashmir, and Punjab provinces (Blyth, 1954), including Ayubia National Park. The putative range of the Kashmir red fox falls within the intermediate altitude habitat between the montane red fox (V.v. montana) and white footed red fox (V.v. pusilla) distributions (Roberts, 1997), and therefore its genetic affinity towards the Palearctic or Holarctic maternal lineage remains unresolved.

Studies focusing on the ecology, distribution and diet of the red fox are scarce in Pakistan, with the majority of studies being conducted in Europe and North America. The red fox is a generalist predator and has a broad diet which includes invertebrates, small mammals, birds, fishes, fruits and carrion (Osborn and Helmy, 1980; MacDonald, 1981; Jędrzejewski and Jędrzejewska, 1992; Dell'Arte et al., 2007). However, its diet composition may vary depending upon various factors like habitat type (Hartova-Nentvichova et al., 2010), prey availability (Leckie et al., 1998; Sidorovich et al., 2006) and seasonal variation in food availability (Baltrunaite, 2001, 2002). In areas near human habitations, red foxes may utilize human-derived resources that can have broad effects on the ecosystem, such as altering the red fox's role as a seed disperser (Cancio et al., 2017) and shifting red fox density in the landscape (Panek and Bresinski, 2002). The only other study on red fox diet in Pakistan was from Pir Lasura National Park in the Himalayan foothills of Pakistan, which red foxes were found to consume wild prey (18\% of diet), domestic prey (51\%) and plants (28\%) (Akrim et al., 2019). In this study, we investigated the occurrence of red fox in the Ayubia National Park, the distribution of red fox maternal lineages in Ayubia National Park and across Northern Pakistan, and red fox diet composition in the study area.

\section{Materials and Methods}

\subsection{Study area}

This study was conducted from August 2017 to July 2018 at Ayubia National Park ( $34^{\circ} .1$ to $34.38^{\circ} \mathrm{N} ; 73.228^{\circ}$ to $73.271^{\circ} \mathrm{E}$ ), which is located in Abbottabad District of Khyber Pakhtunkhwa province, Pakistan. The Park comprises of approximately 312 hectares (8,184 acres) and is the only protected moist temperate region of Pakistan. The area comprises of temperate cone-bearing forests, temperate deciduous forests and sub-alpine meadows, as well as falls within the lesser Himalayas with a mean elevation range of 1,450 to $3,033 \mathrm{~m}$ above the sea level (Lodhi, 2007). Ayubia National Park is surrounded by seven major villages and three small towns of Thandiani, Nathiagali and Khanspur. The mean annual rainfall and temperature ranges are $1500 \mathrm{~mm}$ and $11^{\circ} \mathrm{C}$, respectively (Ahmad and Afza, 2014). The area receives monsoon rains during summer (July and August) and heavy snowfall in winter at upper elevations. The growing period ranges from late March to end of September each year with an average daytime temperature of 3 to $11^{\circ} \mathrm{C}$ (Franklin, 1995; Kruckeberg, 2004). A total of 31 species of native mammals including the red fox inhabit this park, along with a variety of bird species. In addition, the people living in and around the National park keep domestic animal species (sheep, goat, cow, buffalo, donkey) at their houses, which graze freely during daytime in the park (Lodhi, 2007). However, at present no estimates of these domestic animals in the park are available.

\subsection{Spatial distribution}

The occurrence of red fox in the study area was determined by conducting fortnightly field surveys on foot in potential habitats of the Park at different elevations. 
The field surveys were carried out during seven field trips to the study area, during which direct and indirect signs (such as scats, foot marks etc.) of the fox species were searched and recorded. The scats of the species were identified in the field by the authors based on the morphological characteristics of the scats including shape, size and composition. The survey was conducted on the available trails in the park (Figure 1). The survey team comprised of four people, including two watchers from the staff of the Ayubia National Park. The geographical coordinates of the positive sites were recorded using a Geographical Positioning System (GPS; Garmin eTrex Vista) and used later on to develop a distribution map of the species in the study area.

In order to confirm the occurrence of the fox species in Ayubia National Park, we also installed camera traps $(\mathrm{n}=6)$ in the study area. The camera traps (Reconyx Company) were installed at Lalazar track of the Ayubia National Park to record photographic evidence of red fox occurrence (Figure 2). The cameras were installed for six consecutive days from August 22 to 27, 2017. They were used only to confirm the occurrence of the fox in the study area.

\subsection{Genetic analysis}

\subsubsection{Laboratory procedures}

To confirm the red fox presence and investigate its phylogenetic status, we sequenced the mitochondrial cytochrome-B region of scat samples $(n=3)$ from the study area at the Mammalian Ecology and Conservation Unit of the Veterinary Genetics Laboratory at the University of
California, Davis, USA. We also included red fox samples from regions of Gilgit-Baltistan, Khyber Pakhtunkhwa, and Islamabad Capital Territory for the analysis (Table 1). During the process, Deoxyribonucleic acid (DNA) was extracted from approximately $15 \mathrm{mg}$ of feces using the QIAGEN DNeasy Blood \& Tissue Kit (Qiagen Inc., Valencia CA). The total volume of DNA extracts from each scat sample was $50 \mu \mathrm{L}$. Blank extractions were systematically performed to monitor possible contaminations. We used polymerase chain reaction (PCR) and performed sequencing in forward direction using following cyt $\mathrm{b}$ primers:

RF14724 (5'-CAACTATAAGAACATTAATGACC-3') and

RF15149 (5'- CTCAGAATGATATTTGTCCTC-3')

targeting about 425-bp of the cytochrome b of the mitochondrial DNA. We used a thermal profile of $94^{\circ} \mathrm{C}$ for $10 \mathrm{~min}$, followed by 40 cycles at $94^{\circ} \mathrm{C}$ for $30 \mathrm{~s}, 50^{\circ} \mathrm{C}$ for $30 \mathrm{~s}$ and $72{ }^{\circ} \mathrm{C}$ for 45 s; followed by a 10 -min extension period at $72{ }^{\circ} \mathrm{C}$. The sequencing was carried out on the Illumina Genome Analyzer IIx (Illumina Inc.). The sequence reads were manually aligned using Sequencher 5.4 (Gene Codes, Inc., Ann Arbor, Michigan). Subsequently, we used the Basic Local Alignment Search Tool (BLAST; Altschul et al., 1990) to identify species for each sample that had a high match to reference sequences in Genbank.

\subsubsection{Phylogenetic analysis}

To place the red fox samples from Ayubia National Park in context with the region, we have included 43 newly red fox samples from the Northern Pakistan region and 97 previously sequenced worldwide red fox samples (Table S1) originating from Statham et al.

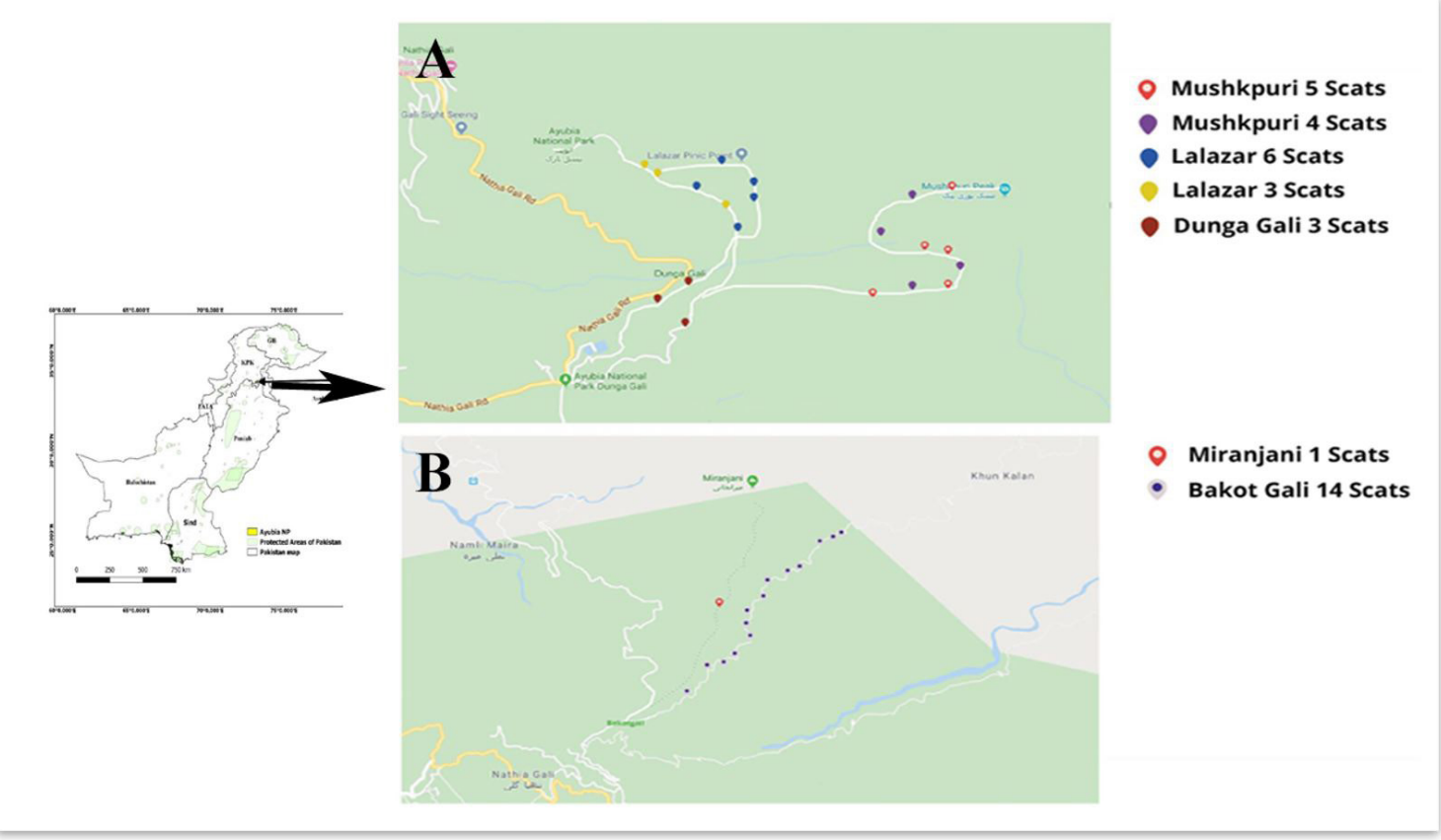

Figure 1. Map showing details of tracks surveyed for collecting signs (scats and camera traps) of red fox (Vulpes vulpes) in Ayubia National Park, Abbottabad Wildlife Division, Abbottabad District, Pakistan.A) showing five sampling sites (at Mushakpuri, Lalazar and Dunga Gali) for red fox scat collection while B) showing remaining two sites (at Miranjani and Bakot Gali) where red fox scats were collected. 
(2014). We also included the corsac fox (Vulpes corsac) as an outgroup from Genbank (NCBI ID =JF489127). After trimming in Sequencher, we aligned 304 bp of the cytochrome B sequence of our red fox samples using ClustalX 2.1 (Larkin et al., 2007). After alignment, a Bayesian coalescent-based phylogenetic analysis was performed using BEAST 2.5.2 (Heled and Drummond, 2010). We applied the HYK + F + G4 model of nucleotide substitution, which was selected as the best-fit model based on maximum likelihood using ModelFinder (Kalyaanamoorthy et al., 2017) within the IQ-tree version 1.6.12 (Nguyen et al., 2015). We performed 50,000,000 generations, sampling every 5000 generations, which we then retained 10,000 samples. Based on the results using Tracer 1.5 (Drummond and Rambaut, 2007), we designated $10 \%$ of the first trees as burn-in. The effective sample sizes were above 200 for all parameters.

\subsection{Diet composition}

The diet composition of red fox was investigated by analysis of its scats. For this purpose, scats $(n=36)$ of the species were collected from the study area regularly on a fortnightly basis during surveys. The red fox scats were identified in the field based upon their morphology, shape and composition and subsequently were collected in selfsealing polythene samples bags. The collected scats were brought to the laboratory, sun dried and then analyzed following Mukherjee et al. (1994). The disintegrated components of the scats were segregated into identifiable groups including animal-based prey and plant-based prey item. To identify between wild and domestic prey species, we prepared light microscopic slides (whole mount and scale replica) of the hair recovered from the scats and compared them to reference hairs. To calculate the average frequency of occurrence (F) of prey species in scats, we divided the number of scats containing a particular species by the total number of scats and multiplied by 100 . For calculating volume (V), we measured the weight of a particular food item recovered from a scat divided that by total weight of the particular scat and multiplied by 100 .

The total biomass consumed by red fox during current study period was computed following Ackerman et al. (1984) using Formula 1:

$$
Y=1.98+0.035 X
$$

where: $\mathrm{Y}=$ weight of prey consumed per scat; $\mathrm{X}=$ average body weight of the prey.

It is important to note that prey that is not entirely consumed by the foxes results in over-estimate biomass consumption for that specific prey species.

\section{Results}

\subsection{Occurrence of red fox}

Indirect signs of red fox were found at different tracts, mainly in the form of scats (Table 1). The scats of the species were found on five different sampling sites, which include Dunga Galli, Mushkpuri, Miranjani, Lalazar and Bakotgali (Table 1). Maximum numbers of field signs (Figure 1) of fox species (as scats) were found at Bagot Galli site (39\%), followed by Mushkpuri and Lalazar track sites (25\% each), while minimum numbers of indirect signs of the fox were recorded at Miranjani track site (3\% only). Results of camera trap study confirmed the occurrence of fox at Ayubia National Park (Figure 2) with the fox species being captured on four different occasions at various locations on the Lalazar tract sampling site, resulting a total of eight photographs.

Table 1. Details of sampling sites in the Ayubia National Park, and the numbers of scats of the red fox recorded.

\begin{tabular}{|c|c|c|c|c|c|c|c|}
\hline \multirow{2}{*}{ Visits } & \multirow{2}{*}{$\begin{array}{c}\text { Date of } \\
\text { visit }\end{array}$} & \multirow{2}{*}{$\begin{array}{l}\text { sampling } \\
\text { site }\end{array}$} & \multicolumn{2}{|c|}{ GPS Coordinates } & \multirow{2}{*}{$\begin{array}{l}\text { Elevation } \\
(\mathrm{m})\end{array}$} & \multirow{2}{*}{$\begin{array}{c}\text { Distance } \\
\text { walked } \\
(\mathbf{k m})\end{array}$} & \multirow[b]{2}{*}{ Scats } \\
\hline & & & $\begin{array}{c}\text { Starting } \\
\text { Coordinate }\end{array}$ & Ending Coordinate & & & \\
\hline 1 & 17-Aug-17 & Dunga gali & $\begin{array}{l}\text { N34 }{ }^{\circ} 05^{\prime} 67.38^{\prime \prime} \\
\text { E073 } 41^{\prime} 42.14^{\prime \prime}\end{array}$ & $\begin{array}{l}\mathrm{N} 34^{\circ} 05^{\prime} 50.4^{\prime \prime} \\
\mathrm{E} 073^{\circ} 40^{\prime} 84.6^{\prime \prime}\end{array}$ & 2359- 2425 & 4 & 3 \\
\hline 2 & 22-Sep-17 & Lalazar & $\begin{array}{l}\mathrm{N} 34^{\circ} 063^{\prime} 73.8^{\prime \prime} \\
\mathrm{E} 073^{\circ} 40^{\prime} 55.4^{\prime \prime}\end{array}$ & $\begin{array}{l}\mathrm{N} 34^{\circ} 06^{\prime} 33.4^{\prime \prime} \\
\mathrm{E}^{\prime} 073^{\circ} 40^{\prime} 48.0^{\prime \prime}\end{array}$ & 2521-2534 & 1.5 & 3 \\
\hline 3 & 3-Nov-17 & Lalazar & $\begin{array}{l}\mathrm{N} 34^{\circ} 06^{\prime} 36.0^{\prime \prime} \\
\mathrm{E} 073^{\circ} 40^{\prime} 53.8^{\prime \prime}\end{array}$ & $\begin{array}{l}\mathrm{N} 34^{\circ} 06^{\prime} 34.8^{\prime \prime} \\
\mathrm{E} 073^{\circ} 40^{\prime} 51.9^{\prime \prime}\end{array}$ & $2531-2525$ & 4 & 6 \\
\hline 4 & 9-Jan-18 & Mushkpuri & $\begin{array}{l}\mathrm{N} 34^{\circ} 06^{\prime} 14.76^{\prime \prime} \\
\mathrm{E} 073^{\circ} 42^{\prime} 88.40^{\prime \prime}\end{array}$ & $\begin{array}{l}\mathrm{N} 34^{\circ} 05^{\prime} 50.94^{\prime \prime} \\
\mathrm{E}^{\prime} 73^{\circ} 41^{\prime} 67.93^{\prime \prime}\end{array}$ & 2798- 2507 & 4 & 4 \\
\hline 5 & 22-Mar-18 & Miranjani & $\begin{array}{l}\mathrm{N} 34^{\circ} 08^{\prime} 38.16^{\prime \prime} \\
\mathrm{E}^{\prime} 73^{\circ} 40^{\prime} 18.81^{\prime \prime}\end{array}$ & $\begin{array}{l}\mathrm{N} 34^{\circ} 08^{\prime} 38.91^{\prime \prime} \\
\mathrm{E}^{\circ} 73^{\circ} 40^{\prime} 19.65^{\prime \prime}\end{array}$ & 2384- 2779 & 2 & 1 \\
\hline 6 & 23-Mar-18 & Mushkpuri & $\begin{array}{l}\mathrm{N} 34^{\circ} 06^{\prime} 43.78^{\prime \prime} \\
\mathrm{E} 073^{\circ} 40^{\prime} 74.32^{\prime \prime}\end{array}$ & $\begin{array}{l}\text { N34 }{ }^{\circ} 06^{\prime} 09.37^{\prime \prime} \\
\text { E}^{\prime} 73^{\circ} 42^{\prime} 60.48^{\prime \prime}\end{array}$ & 2533- 2776 & 4 & 5 \\
\hline 7 & 5-May-18 & Bakotgali & $\begin{array}{l}\text { N34 } 04^{\circ} 95.96^{\prime \prime} \\
\mathrm{E}^{\prime} 073^{\circ} 39^{\prime} 40.35^{\prime \prime}\end{array}$ & $\begin{array}{l}\text { N34 } 04^{\circ} 47.45^{\prime \prime} \\
\text { E}^{\prime} 73^{\circ} 41^{\prime} 01.71^{\prime \prime}\end{array}$ & 2337- 2476 & 4.6 & 14 \\
\hline Total & & & & & & $24.1 \mathrm{~km}$ & 36 \\
\hline
\end{tabular}




\subsection{Species identification and phylogenetic position}

We used a total of three $(n=3)$ fresh scats of the red fox collected from the field for phylogenetic analysis. Based on the mitochondrial cytochrome $B$ sequences, we have confirmed that red fox is present in Ayubia National Park. Our phylogenetic analysis show that all the Ayubia National Park samples fell into the Holarctic maternal clade. Among the newly sequenced red foxes samples from Pakistan, we found that all the red foxes inhabiting the higher altitude regions of KPK $(n=8)$ and Gilgit Baltistan $(\mathrm{n}=21)$ fall within the Holarctic maternal lineage. The sites within Margalla Hills National Park showed a majority of Holarctic haplotypes $(\mathrm{n}=17)$ and two Palearctic haplotypes. The posterior probability of the node separating the Holarctic clade from the Palearctic and Nearctic clade was 1 (Figure 3). The geographic distribution of red fox cyt-B lineages is given in Figure 4.

\subsection{Diet composition}

The current study encompassed seven field visits to the study area that covered a total distance of approximately $24 \mathrm{~km}$. The maximum number of scats were found at elevation of $2407 \mathrm{~m}(\mathrm{~N}=14)$ to $2529(\mathrm{~N}=09)$ at the Bakot gali and Lalazar tracks (Table 1$)$, while the minimum number of scats was found at the Miranjani $\operatorname{track}(\mathrm{N}=1)$.

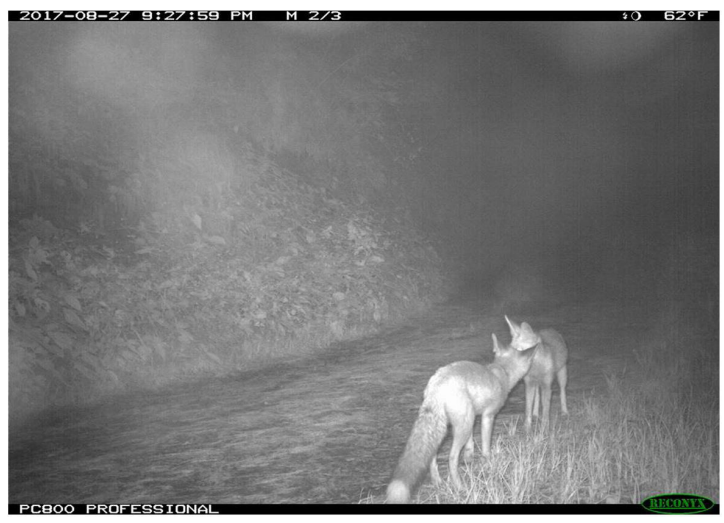

Figure 2. Camera trap photograph of a pair of red foxes (Vulpes vulpes griffithii) recorded at selected sampling site (Lalazar tract) in Ayubia National Park, Abbottabad, during current study.
A total of 36 scat samples were collected from the study area, however, after careful examination and identification, 32 samples were processed for investigating the dietary habits of red fox in the study area. Red fox scat samples $(\mathrm{n}=32$ ) were first measured in the laboratory for their physical characteristics including length, breadth and weight using Vernier Caliper and digital weighing balance. Average length and breadth of scats were $7.43 \pm 3.47 \mathrm{~cm}$, and $2.75 \pm 1.36 \mathrm{~cm}$, respectively while their mean weight was measured to be $2.69 \pm 0.30 \mathrm{~g}$ (Table 2 ).

The prey items recovered from the scat analysis of red fox included hairs, bones, feathers, plant matter (i.e., grass) and other anthropogenic matter (i.e., stones and polythene). Hair contributed maximum to the average frequency of occurrence across scats $(71.85 \% \mathrm{~F})$, followed by seeds $(37.5 \% \mathrm{~F})$, bones $(21.87 \% \mathrm{~F})$, other plant matter like grass $(28.12 \% \mathrm{~F})$, and anthropogenic matter $(62.5 \%$ F) (Figure 5).

For the composition of total diet volume (V) of red fox, animal based diet was the major contributor (59.43\% of total diet volume, $\mathrm{V}$ ), which included mainly hairs (42.9\% V), bones $(16.04 \% \mathrm{~V})$, and feathers $(0.49 \% \mathrm{~V})$. The occurrence of some feathers from fox scats indicates that it occasionally and opportunistically feeds upon birds. Similarly, the occurrence of hairs in fox scats shows it also consumes small mammals like rodents. The plant based diet included seeds, vegetative parts of plants and grasses, which was relatively less consumed $(19.02 \% \mathrm{~V})$ compared to the animal based diet by red fox in this study (Figure 6).

\subsubsection{Animal prey species}

Six mammalian prey species (four wild and two domestic) were identified in the diet of the red fox (Table 3). The mammalian prey species included donkey (Equus asinus), flying squirrel (Pteromyini sp.), Cape hare (Lepus capensis), domestic sheep (Ovis aries), Himalayan palm civet (Paguma larvata) and house mouse (Mus musculus). Among wild prey, flying squirrel and Cape hare were the most frequently consumed by red fox in the study area, followed by house mouse and Himalayan palm civet. However, Himalayan palm civet was the most voluminously $(27.56 \% \mathrm{~V})$ consumed prey, followed by Cape hare $(13.4 \% \mathrm{~V})$ and flying squirrel (11.52\% V).

Table 2. Morphological characteristics of scat samples of red fox that were collected from the Ayubia National Park.

\begin{tabular}{|c|c|c|c|c|}
\hline Site Name & No. of scats & Length (cm) & Breadth $(\mathbf{c m})$ & Weight (g) \\
\hline Dunga gali & 3 & $0.87-2.62$ & $1.5-2.60$ & $2.74-31.58$ \\
\hline Lalazar & 5 & 2.819-22.09 & $3.55-17.27$ & $1.43-8.06$ \\
\hline Muskpuri & 9 & $0.932-3.42$ & $0.47-1.38$ & 2.33 \\
\hline Miranjani & 1 & 0.796 & 1.689 & $1.01-2.70$ \\
\hline Bakotgali & 14 & $1.79-5.97$ & $1.04-3.964$ & $0.52-4.04$ \\
\hline Total & 32 & 37.183 & 13.782 & 24.68 \\
\hline Mean \pm SE & & $7.436 \pm 3.472$ & $2.756 \pm 1.365$ & $2.694 \pm 0.304$ \\
\hline
\end{tabular}

*SE: Standard Error 


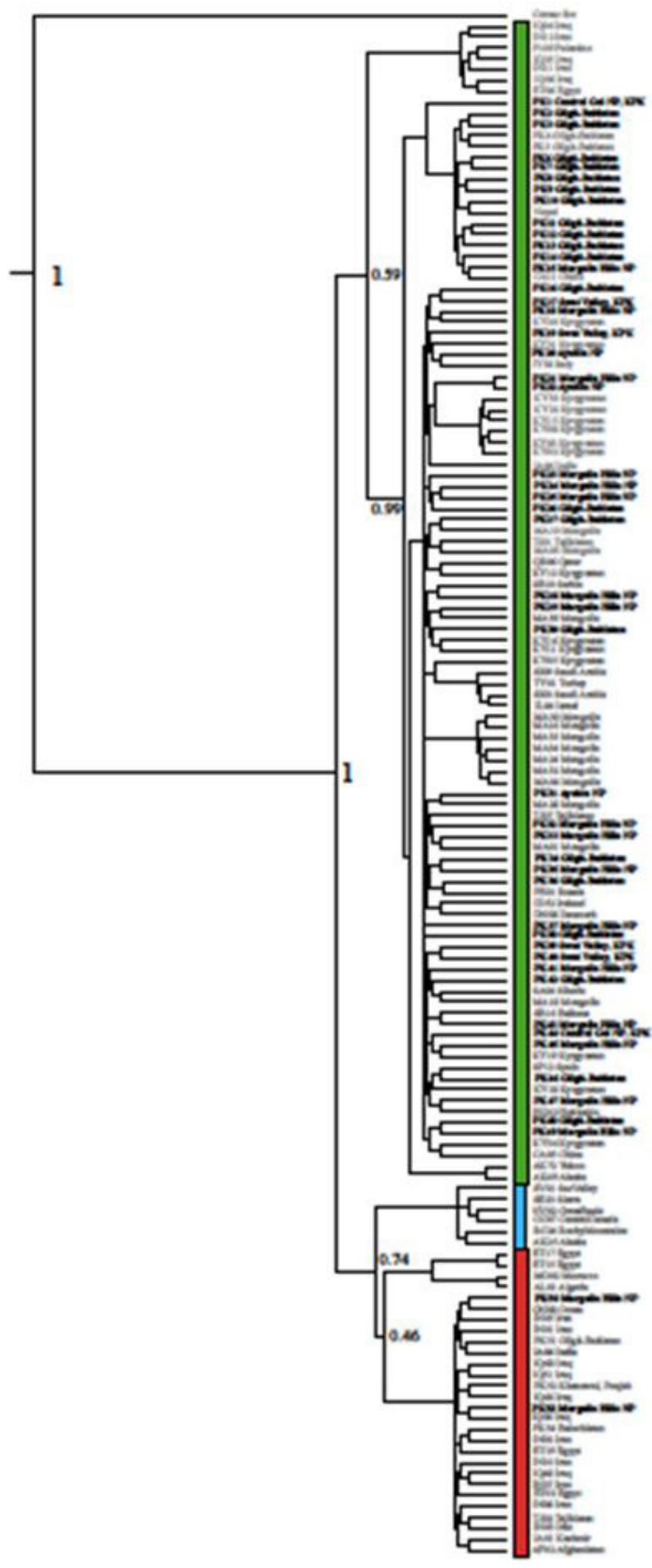

Figure 3. Phylogenetic tree of 140 red foxes using 304bp of the mitochondrial cytochrome B sequence. The posterior probability is indicated at the relevant node positions. The tip labels refer to the sample IDs in Table S1 with labels in black indicated newly sequenced samples from this study. Red bar indicates the Palearctic maternal lineage, blue indicates Nearctic maternal lineage, and green indicates Holarctic maternal lineage. KPK = Khyber Pakhtunkhwa administrative province in Pakistan, NP = National Park. 


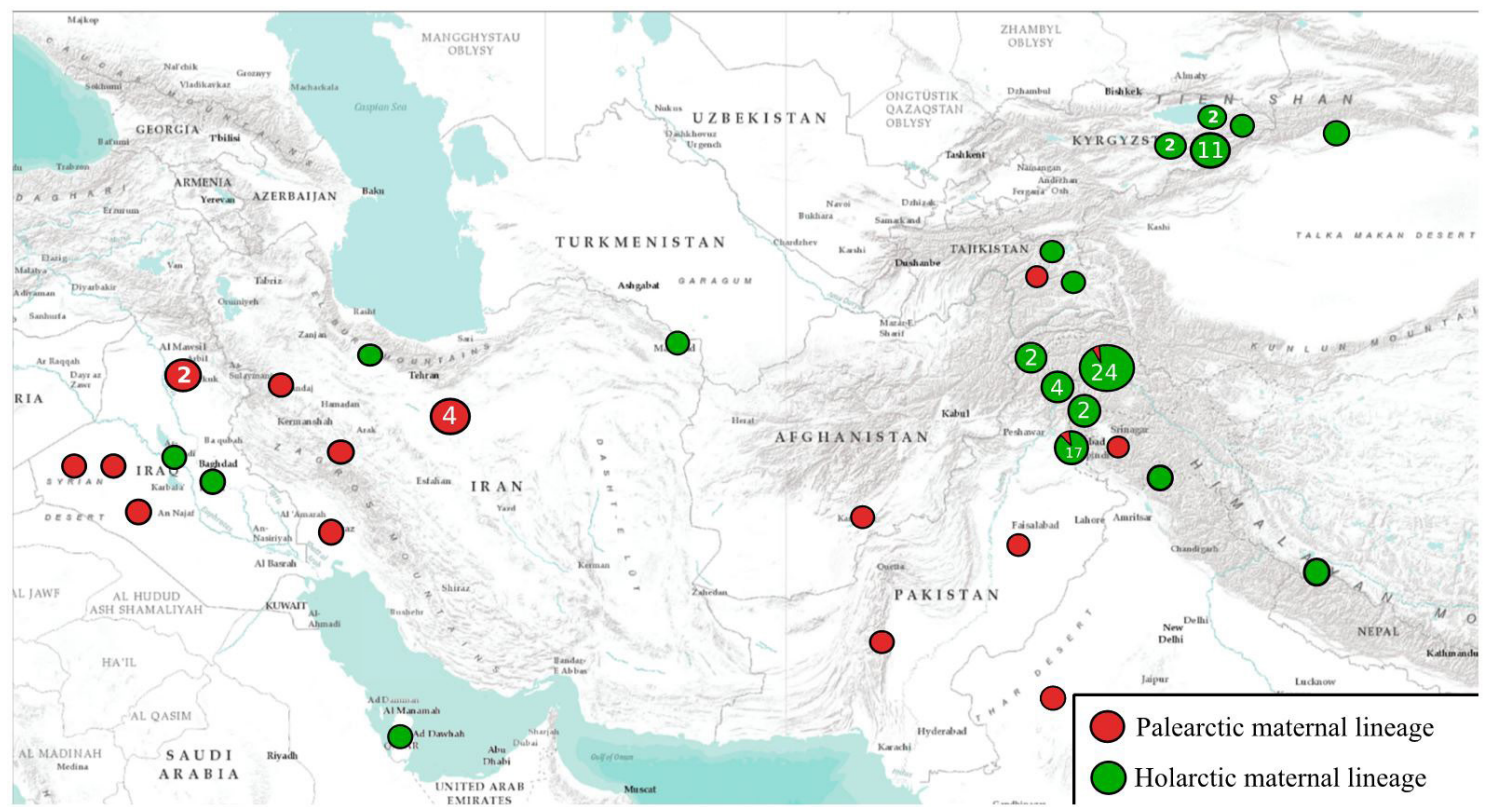

Figure 4. Distribution of the Holarctic and Palearctic maternal lineages of red foxes using 304bp of the mitochondrial cytochrome B sequences. Genetics samples in the distribution map originate from the current study (Statham et al., 2014; Werhahn et al., 2017).

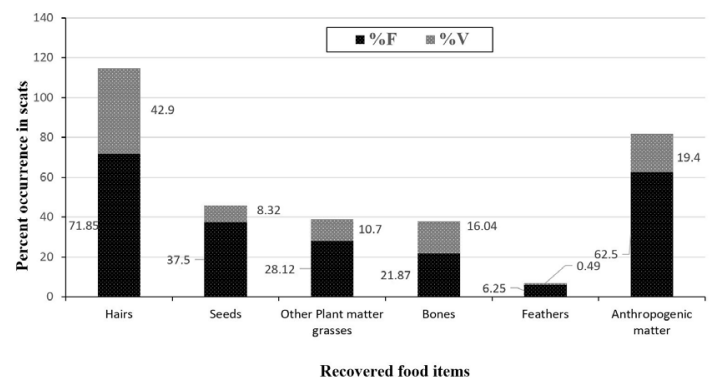

Figure 5. Percent frequency $(\% \mathrm{~F})$ and percent volume $(\% \mathrm{~V})$ occurrence of recovered food items from 32 scats of red foxes from Ayubia National Park.

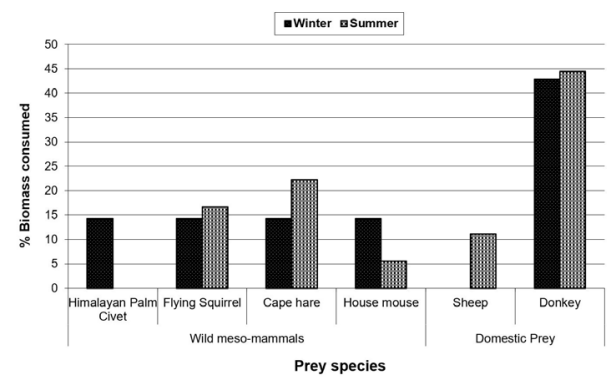

Figure 6. Seasonal variation (winter and summer) in biomass consumption of prey species by red fox inhabiting Ayubia National Park, Pakistan.

Table 3. Details of prey species (\%F and \%V) identified from the scats of the red fox collected from Ayubia National Park.

\begin{tabular}{|c|c|c|c|c|}
\hline S. No. & Prey species & Scientific name & $\% F$ & $\% \mathrm{~V}$ \\
\hline \multicolumn{5}{|l|}{ Wild prey } \\
\hline 1 & Flying squirrel & Pteromyini sp. & 15.62 & 18.01 \\
\hline 2 & Himalayan Palm Civet & Paguma larvata & 6.25 & 43.07 \\
\hline 3 & House mouse & Mus musculus & 9.37 & 13.58 \\
\hline 4 & Cape hare & Lepus capensis & 18.75 & 20.95 \\
\hline \multicolumn{5}{|l|}{ Domestic prey } \\
\hline 5 & Donkey & Equus asinus & 43.75 & 24.68 \\
\hline 6 & Domestic sheep & Ovis aries & 6.25 & 6.74 \\
\hline \multicolumn{5}{|l|}{ Plant food } \\
\hline 7 & Katchmach & Solanum nigrum & 15.62 & 34.40 \\
\hline 8 & Chirata & Swertia sp. & 9.37 & 26.41 \\
\hline 9 & Kala amlok & Diospyros lotus & 9.37 & 19.81 \\
\hline 10 & Chonkaath & Chonkaath sp. & 6.25 & 16.02 \\
\hline
\end{tabular}


Among domestic prey (scavenged by red fox), donkey contributed the highest $(43.75 \% \mathrm{~F})$ in the total diet of red fox, followed by sheep (Table 4). The shape of one of the down feathers recovered from the scat samples of the red fox resembled House sparrow (Passer domesticus).

\subsubsection{Plant diet}

The seeds of plants identified from the scats included four species: Swertia (local name Chirata), Solanum nigrum (Katchmach), Diospyros lotus (Kala amlok) and Chonkaath (Table 3). In terms of percentage frequency (\%F) Katchmach (Solanum nigrum) contributed highest $(15.62 \% \mathrm{~F})$, followed by Kala amlok (Diospyros lotus) and Chirata (Swertia) (9.37\%F), while Chonkaath contributed the least (6.25\%F). In accordance with percentage volume (\%V), Katchmach (Solanum nigrum) was most heavily consumed $(6.88 \% \mathrm{~V})$ followed by Chirata (Table 3).

\subsubsection{Prey biomass consumption}

In terms of total biomass consumption, domestic prey dominated at $89.8 \mathrm{~kg}$ of the total diet over wild mesomammals at $10.18 \%$ (Table 4). Donkey was a major food item that constituted $80.68 \mathrm{~kg}$ of biomass among domestic animals, followed by domestic sheep ( $45.2 \mathrm{~kg}$ ). Among wild prey, Himalayan palm civet was the major contributor of biomass ( $5.1 \mathrm{~kg}$ ), followed by cape hare while flying squirrel and house mouse contributed least (Table 4).

\subsubsection{Seasonal variation}

Diet composition of red fox showed seasonal variation in its consumption (Figure 6). During winter (from October to March), the fox consumed slightly more wild prey $(57.12 \mathrm{~kg}$, $\mathrm{n}=14$ scats in the winter) compared to summer (April to September) season ( $44.43 \mathrm{~kg}, \mathrm{n}=18$ scats in the summer). Similarly, the red fox relied more on domestic prey in summer season ( $55.55 \mathrm{~kg}$ ) compared to winter ( $42.85 \mathrm{~kg}$ ) Among wild prey, Himalayan palm civet was only consumed during winter while domestic sheep was only consumed during summer season. The Cape hare was the major wild prey of red fox during summer season followed by flying squirrel (Figure 6). The winter and summer diet of the red fox was compared through student's paired t-test, which showed that diet composition differed non-significantly ( $\mathrm{df}=5, \mathrm{t}=2.01, p=0.49)$ in the two seasons.

\section{Discussion}

Our study contributes to a gap in knowledge on red fox occurrence, phylogenetic diversity, and diet composition in Pakistan. We have confirmed that the red fox is present in Ayubia National Park through field photographs by camera traps and DNA analysis of the cytochrome B region. The phylogenetic analysis showed that red foxes in Ayubia National Park, surrounding temperate mountain regions, and high-altitude regions of Gilgit-Baltistan are part of the Holarctic red fox maternal lineage. The scat analysis for diet composition revealed animal-based (69.33\%) and plant-based (19.02\%) food components along with some anthropogenic matter (19.4\%). While our analyses show little seasonality in the red fox diet within the study area, our results on red fox diet should be considered preliminary due to small sample sizes. Overall, this study provides insight into the occurrence, genetic distinctiveness, and diet composition of the red fox in a region where there is little scientific knowledge of this important and widely distributed mammal.

Ayubia National Park consists of sub-alpine meadows and moist temperate, sub-tropical pine forests. Based mainly on scats, the field signs of fox were found at different tracts in the Park, which included Dunga gali, Mushkpuri, Miranjani, Lalazar and Bakotgali. In Machiara National Park in Azad Jammu \& Kashmir, the Kashmir hill red fox was commonly distributed throughout the national park at elevations ranging from 1500 to $3300 \mathrm{~m}$ (Awan et al., 2004). We have recorded the fox species up to maximum of 2258 m elevation in our study region, in correspondence to the elevational range described in Awan et al. (2004).

Table 4. Prey biomass consumption by red fox in Ayubia National Park.

\begin{tabular}{|c|c|c|c|c|c|}
\hline Prey species & $\begin{array}{c}\text { Assumed weight } \\
\text { (kg) }\end{array}$ & Biomass per scat & Number of scats & $\begin{array}{c}\text { Biomass } \\
\text { consumed (kg) }\end{array}$ & $\begin{array}{c}\text { Biomass } \\
\text { Consumption \% }\end{array}$ \\
\hline \multicolumn{6}{|l|}{ Domestic prey } \\
\hline Domestic sheep & 45 & - & - & - & - \\
\hline Donkey & 80 & 3.78 & 6 & 80.68 & 89.8 \\
\hline Sub-total & 125 & 3.78 & 6 & 80.68 & 89.8 \\
\hline \multicolumn{6}{|c|}{ Wild Meso-mammals } \\
\hline Flying squirrel & 0.14 & 3.95 & 2 & 0.72 & 0.8 \\
\hline $\begin{array}{l}\text { Himalayan Palm } \\
\text { civet }\end{array}$ & 4.3 & 2.56 & 2 & 5.1 & 5.67 \\
\hline House mouse & 0.019 & 5.46 & 2 & 0.63 & 0.7 \\
\hline Cape hare & 2 & 4.8 & 2 & 2.71 & 3.01 \\
\hline Total & 6.459 & 11.31 & 8 & 9.16 & 10.18 \\
\hline
\end{tabular}


Similar to the gray wolf and brown bear, most of the red fox phylogenetic diversity is centered in the southern portion of its global range (Sharma et al., 2004; Ashrafzadeh et al., 2016; Lan et al., 2017; Statham et al., 2014). Based on our limited sampling and previous studies, our results suggest that the basal Palearctic maternal lineage is primarily found in the lower altitude regions of Pakistan (Statham et al., 2014). In contrast, our samples across the Kashmir hill red fox range (Ayubia National Park, Swat Valley, and Chitral Gol National Park of KPK) and the montane red fox range in Gilgit-Baltistan all fell within the Holarctic maternal lineage. While a single Palearctic haplotype from a previously sequenced red fox sample was found near Gilgit, this museum-based sample was collected in the late 1800's and may have inaccurate origins (Statham et al., 2014). If this sample's location is correct, there may be a very low frequency of Palearctic haplotypes in the high altitude red fox population that was undetected by our study. Overall, our results suggest that the majority of the high altitude red foxes of Northern Pakistan are part of the Holarctic maternal lineage and, therefore, the presence of this lineage in Northern Pakistan may have originated from a major expansion event in Eurasia during the last glaciation (Statham et al., 2014).

It is interesting to note that there was a low frequency of Palearctic maternal haplotypes found in Margalla Hills National Park, which lies at the junction of the Pothwar Plateau and the Himalayan range. For amphibians and reptiles, Margalla Hills National Park represents the most northernmost range of species found on the plains and the most southern extent of species found in the Himalaya (Masroor, 2011). Based on its smaller body size, it has been suggested that the red fox in the Punjab Salt Range is the white footed fox V.v. pusilla (Roberts, 1997), in which the Potwar plateau and/or the region of Margalla Hills National Park could possibly be the area of secondary contact between the subspecies V.v pusilla and V.v. griffithii. A phylogeographic break in red foxes was previously inferred at the junction of the plains and mountainous regions of Pakistan (Statham et al., 2014), and our results suggest this region may be a transition zone between populations with palearctic haplotypes in the plains to Holarctic haplotypes in the mountains. Further research using the mitochondrial D-loop, nuclear genetic markers, and expanded geographic sampling will give higher resolution into the distribution of red fox subspecies and whether the Palearctic and Holarctic maternal lineages interbreed with each other. More broadly, this resolution can give insight into the historical processes that have shaped patterns of regional species diversity in South and Central Asia.

Knowledge of a predator's diet is vital to understand its ecology and to predicting its effect on the dynamics of prey populations (Oli, 1993). Our results are consistent with the red fox being an omnivore having a diverse diet, as highlighted in other studies (Basuony et al., 2005; Baker et al., 2006; Goldyn et al., 2003; Soe et al., 2017). The analysis of scats revealed both animal-based (69.33\%) and plant-based (19.02\%) food components, along with some anthropogenic matter (19.4\%; i.e., plastic pieces, stones etc.). Among wild prey, cape hare and Himalayan palm civet were the most consumed followed by flying squirrel. These results are similar with feeding patterns of the red fox studied in the Mediterranean landscapes (Blondel and Aronson, 1999; Aranzabal et al., 2008) showing that mammals are the most important trophic group for red fox diet, particularly the European brown hare, followed by arthropods and plants. In contrast, the desert-adapted white footed fox (V.v. pusilla) consume most frequently fruits and insects in the Thar Desert of Western India (Wilson and Dookia, 2019). In Pir Lasura National Park in Azad Kashmir, red fox was found to consume a similar frequency of domestic prey (50.9\%) to the red foxes in Ayubia National Park (50\%). Although red foxes in Pir Lasura National Park primarily consumed poultry as domestic prey, we did not find any sign of poultry in our samples, possibly due to a lack of poultry in the study area or inadequate sample sizes. We caution that while the biomass consumption is high for domestic prey, it is likely due to the high weight of the domestic prey and that red foxes probably scavenged the carcasses opportunistically.

Lastly, we documented that almost $20 \%$ of red fox diet was plant-based, which were identified by seeds in the scats. Red foxes have been recognized as an important for dispersal and germination of seeds of the Mediterranean hackberry (Juan et al., 2006). Many other studies have highlighted the consumption of plant-based material in red fox diet (Murdoch et al., 2009, D'hondt et al., 2011; Díaz-Ruiz et al., 2013; Cancio et al., 2017; Reshamwala et al., 2018). In Pir Lasura National Park in Pakistan, red foxes showed that plants made up $27.54 \%$ of the total frequency across 92 scats (Akrim et al., 2019). Interestingly, one of the most consumed plants by red foxes in our study was Chirata (Swertia sp.), which is a used frequently as a traditional medicinal plant for various ailments, such as fever, constipation, upset stomach, loss of appetite, and intestinal worms (Kumar and van Staden, 2016). In addition to a larger sample size of scats, further research on whether consumed seeds show higher and more rapid germination than seeds that are not digested by red foxes has the potential to evaluate whether Kashmir Hill red foxes are acting as seed dispersers.

\section{Conclusion}

Our study confirms that red fox occurs in the Ayubia National Park with an elevational range between $2300 \mathrm{~m}$ to $2550 \mathrm{~m}$. Based on our samples, the sub species (Kashmir hill red fox) in Ayubia National Park is part of the Holarctic maternal lineage. Furthermore, phylogenetic analysis using 140 red fox sequences showed that both the Kashmir hill and montane red fox sub-species in the mountainous regions of Northern Pakistan are part of the Holarctic maternal lineage, whereas red fox samples at the lower altitude regions of Pakistan fall within the basal Palearctic maternal lineage. In Ayubia National Park, the red fox consumes mostly animal based diet (approximately $70 \%$ ), which includes four wild meso-mammals and two domestic prey species. Plants comprise of $19 \%$ of the red fox diet, suggesting red foxes may facilitate seed dispersal of some plant species. 


\section{Acknowledgements}

The authors are highly grateful to Khyber Pakhtunkhwa Wildlife Department for providing partial funding for the current study through their "Strengthening of National Parks" project. We thank Mr. Mehdi Sadpara and Mr. Saeed-ul-Islam for collecting red fox samples. The grant for sequencing the fox samples was under the Rufford Foundation Small Grant award to Hira Fatima. We also thank Stevi Vanderswan for lab assistance as well as Mark Statham and Ben Sacks for discussion.

\section{References}

ABLES, E.D., 1975. Ecology of the red fox in North America. In: M.W. FOX, ed. The wild canids: their systematics, behavioral ecology and evolution. New York: Van Nostrand Reinhold Co., pp. 216-236.

ACKERMAN, B.B., LINDZEY, F.G. and HEMKER, T.P., 1984. Cougar food habits in southern Utah. The Journal of Wildlife Management, vol. 48, no. 1, pp. 147-155. http://dx.doi.org/10.2307/3808462.

AHMAD, H. and AFZA, R., 2014. Nesting places of Koklass and Kalij Pheasants, associated plants and habitat losses in Western Himalayas. In: North America Congress for Conservation Biology (NACCB), 2014, Missoula, MT. Corvallis: Conservation Biology Institute.

AKRIM, F., MAHMOOD, T., NADEEM, M.S., DHENDUP, T., FATIMA, H. and ANDLEEB, S., 2019. Diet composition and niche overlap of two sympatric carnivores: Asiatic jackal Canis aureus and Kashmir hill fox Vulpes vulpes griffithii, inhabiting Pir Lasura National Park, northeastern Himalayan region, Pakistan. Wildlife Biology, vol. 2019, no. 1, pp. 1-9. http://dx.doi.org/10.2981/ wlb.00440.

ALTSCHUL, S.F., GISH, W., MILLER, W., MYERS, E.W., and LIPMAN, D.J., 1990. Basic local alignment search tool. Journal of Molecular Biology, vol. 215, pp. 403-410.

ARANZABAL, I., SCHMITZ, M.F., AGUILERA, P. and PINEDA, F.D., 2008. Modelling of landscape changes derived from the dynamics of socioecological systems: a case of study in a semiarid Mediterranean landscape. Ecological Indicators, vol. 8, pp. 672-685. http://dx.doi.org/10.1016/j.ecolind.2007.11.003.

ASHRAFZADEH, M.R., KABOLI, M. and NAGHAVI, M.R., 2016. Mitochondrial DNA analysis of Iranian brown bears (Ursus arctos) reveals new phylogeographic lineage. Mammalian Biology, vol. 81, no. 1, pp. 1-9. http://dx.doi.org/10.1016/j. mambio.2015.09.001.

AWAN, M.S., MINHAZAND, R.A. and AHMED, K.B., 2004. Distribution, food and habitat preferences of small mammals in Machaira National Park, district Muzaffarabad, Azad Kashmir, Pakistan. Punjab University Journal of Zoology, vol. 19, pp. 17-31.

BAKER, P., FURLONG, M., SOUTHERN, S. and HARRIS, S., 2006. The potential impacts of red fox Vulpes vulpes predation in agricultural landscapes in lowland Britain. Wildlife Biology, vol. 12, no. 1, pp. 39-50. http://dx.doi.org/10.2981/09096396(2006)12[39:TPIORF]2.0.CO;2.

BALTRUNAITE, L., 2001. Feeding habits, food niche overlap of red fox (Vulpes vulpes) and pine marten (Martes martes) in hilly moraine highland, Lithuania. Ecología, vol. 2, pp. 27-31.

BALTRUNAITE, L., 2002. Diet composition of the red fox (Vulpes vulpes) pine marten (Martes martes) and raccoon dog (Nyctereutes procyonoides) in clay plain landscape, Lithuania. Acta Zoologica, vol. 4, no. 4, pp. 362-368. http://dx.doi.org/10.1080/1392165 7.2002.10512525.
BASUONY, M., SALEH, M., RAID, A. and FATHY, W., 2005. Food composition and feeding ecology of the Red Fox Vulpes vulpes (Linnaeus, 1758) in Egypt. Egyptian Journal of Biology, vol. 7, pp. 96-102.

BLONDEL, J. and ARONSON, J., 1999. Biology and wildlife of the Mediterranean region. Oxford: Oxford University Press.

BLYTH, E., 1854. Report of the curator, Zoological Department. Journal of the Asiatic Society of Bengal, vol. 23, pp. 737-740.

CANCIO, I., GONZÁLEZ-ROBLES, A., BASTIDA, J.M., ISLA, J., MANZANEDA, A.J., SALIDO, T. and REY, P.J., 2017. Landscape degradation affects red fox (Vulpes vulpes) diet and its ecosystem services in the threatened Ziziphus lotus scrubland habitats of semiarid Spain. Journal of Arid Environments, vol. 145, pp. 24-34. http://dx.doi.org/10.1016/j.jaridenv.2017.05.004.

D'HONDT, B., VANSTEENBRUGGE, L., VAN DEN BERGE, K., BASTIAENS, J. and HOFFMANN, M., 2011. Scat analysis reveals a wide set of plant species to be potentially dispersed by foxes. Plant Ecology and Evolution, vol. 144, no. 1, pp. 106-110. http://dx.doi. org/10.5091/plecevo.2011.472.

DELL'ARTE, G.L., LAAKSONEN, T., NORRDAHL, K. and KORPIMÄKI, E., 2007. Variation in the diet composition of a generalist predator, the red fox, in relation to season and density of main prey. Acta Oecologica, vol. 31, no. 3, pp. 276-281. http://dx.doi. org/10.1016/j.actao.2006.12.007.

DÍAZ-RUIZ, F., DELIBES-MATEOS, M., GARCÍA-MORENO, J.L., LÓPEZ-MARTÍN, J.M., FERREIRA, C. and FERRERAS, P., 2013. Biogeographical patterns in the diet of an opportunistic predator: the red fox Vulpes vulpes in the Iberian Peninsula. Mammal Review, vol. 43, no. 1, pp. 59-70. http://dx.doi.org/10.1111/j.13652907.2011.00206.x.

DRUMMOND, A.J. and RAMBAUT, A., 2007. BEAST: Bayesian evolutionary analysis by sampling trees. BMC Evolutionary Biology, vol. 7, no. 214. https://doi.org/10.1186/1471-2148-7-214.

FRANKLIN, J., 1995. Predictive vegetation mapping: geographic modelling of biospatial patterns in relation to environmental gradients. Progress in Physical Geography, vol. 19, no. 4, pp. 474-499. http://dx.doi.org/10.1177/030913339501900403.

GOLDYN, B., HROMADA, M., SURMACKI, A. and TRYJANOWSKI, P., 2003. Habitat use and diet of the red fox Vulpes vulpes in an agricultural landscape in Poland. Zeitschrift fur Jagdwissenschaft, vol. 49, pp. 191-200.

HARTOVÁ-NENTVICHOVÁ, M., ŠÁLEK, M., ČERVENÝ, J. and KOUBEK, P., 2010. Variation in the diet of the red fox (Vulpes vulpes) in mountain habitats: effects of altitude and season. Mammalian Biology, vol. 75, no. 4, pp. 334-340. http://dx.doi.org/10.1016/j. mambio.2009.09.003.

HELED, J. and DRUMMOND, A.J., 2010. Bayesian Inference of Species Trees from Multilocus Data. Molecular Biology and Evolution, vol. 27, no. 3, pp. 570-580.

JĘDRZEJEWSKI, W. and JĘDRZEJEWSKA, B., 1992. Foraging and diet of the red fox Vulpes Vulpes in relation to variable resources in Białowieża National Park, Poland. Echography, vol. 15, no. 2, pp. 212-220. http://dx.doi.org/10.1111/j.1600-0587.1992.tb00027.x.

JUAN, T., SAGRARIO, A., JESÚS, H. and CRISTINA, M.C., 2006. Red fox (Vulpes vulpes L.) favour seed dispersal, germination and seedling survival of Mediterranean Hackberry (Celtis australis L.). Acta Oecologica, vol. 30, no. 1, pp. 39-45.

KALYAANAMOORTHY, S., MINH, B.Q., WONG, F.K.F., VON HAESELER, A. and JERMIIN, L.S., 2017. Model Finder: fast model selection for accurate phylogenetic estimates. Nature Methods, vol. 14, no. 6, pp. 587-589. http://dx.doi.org/10.1038/nmeth.4285. PMid:28481363. 
KRUCKEBERG, A.R., 2004. Geology and plant life: the effects of landforms and rock types on plants. Washington: University of Washington Press.

KUMAR, V. and VAN STADEN, J., 2016. A review of Swertia chirayita (Gentianaceae) as a traditional medicinal plant. Frontiers in Pharmacology, vol. 6, pp. 308. http://dx.doi.org/10.3389/ fphar.2015.00308. PMid:26793105.

KUTSCHERA, V.E., LECOMTE, N., JANKE, A., SELVA, N., SOKOLOV, A.A., HAUN, T., STEYER, K., NOWAK, C. and HAILER, F., 2013. A range-wide synthesis and timeline for phylogeographic events in the red fox (Vulpes vulpes). BMC Evolutionary Biology, vol. 13, no. 1, pp. 114. http://dx.doi.org/10.1186/1471-2148-13-114. PMid:23738594.

LAN, T., GILL, S., BELLEMAIN, E., BISCHOF, R., NAWAZ, M.A. and LINDQVIST, C., 2017. Evolutionary history of enigmatic bears in the Tibetan plateau-Himalaya region and the identity of the yeti. Proceedings. Biological Sciences, vol. 2017, pp. 284.

LARKIN, M.A., BLACKSHIELDS, G., BROWN, N.P., CHENNA, R., MCGETTIGAN, P.A., MCWILLIAM, H., VALENTIN, F., WALLACE, I.M., WILM, A., LOPEZ, R., THOMPSON, J.D., GIBSON, T.J. and HIGGINS, D.G., 2007. Sequence analysis: Clustal W and Clustal X version 2.0. Bioinformatics Applications Note, Vol. 23, no. 21, pp. 2947-2948.

LECKIE, F., THIRGOOD, S.J., MAY, R. and REDPATH, S.M., 1998. Variation in the diet of the red foxes on Scottish moorland in relation to prey abundance. Ecography, vol. 21, no. 6, pp. 599604. http://dx.doi.org/10.1111/j.1600-0587.1998.tb00552.x.

LODHI, A., 2007. Conservation of leopards in Ayubia National Park, Pakistan. Missoula: The University of Montana, 83 p. Master of Science in Wildlife Biology.

MACDONALD, D.W., 1981. Resource dispersion and the social organization of the red fox (Vulpes vulpes). In: Worldwide Furbearer Conference Proceedings, 1981, Frostburg. Baltimore: University of Maryland Press, pp. 918-949.

MACDONALD, D.W., COURTENAY, O., FORBES, S. and MATHEWS, F., 1999. The red fox (Vulpes vulpes) in Saudi Arabia: looseknit groupings in the absence of territoriality. Journal of Zoology, vol. 249, no. 4, pp. 383-391. http://dx.doi. org/10.1111/j.1469-7998.1999.tb01207.x.

MASROOR, R., 2011. An annotated checklist of amphibians and reptiles of Margalla hills National Park, Pakistan. Pakistan Journal of Zoology, vol. 43, no. 6, pp. 1041-1048.

MUKHERJEE, S., GOYAL, S. and CHELLAM, R., 1994. Standardization of scat analysis techniques for leopards (Panthera pardus) in Gir National Park, Western India. Mammalia, vol. 58, no. 1, pp. 139-143. http://dx.doi.org/10.1515/mamm.1994.58.1.139.

MURDOCH, J.D., BUYANDELGER, S. and CYPHER, B.L., 2009. Patterns of seed occurrence in corsac and red fox diets in Mongolia. Journal of Arid Environments, vol. 73, no. 3, pp. 381-384. http:// dx.doi.org/10.1016/j.jaridenv.2008.10.002.

NGUYEN, L.T., SCHMIDT, H.A., VON HAESELER, A. and MINH, B.Q., 2015. IQ-Tree: A fast and effective stochastic algorithm for estimating maximum-likelihood phylogenies. Molecular Biology and Evolution, vol. 32, no. 1, pp. 268-274. http://dx.doi. org/10.1093/molbev/msu300. PMid:25371430.

OLI, M.K., 1993. A key for identification of hair of mammals of a snow leopard (Panthera uncia) habitat in Nepal.Journal of Zoology, vol. 231, no. 1, pp. 71-93. http://dx.doi.org/10.1111/j.1469-7998.1993. tb05354.x.
OSBORN, J., and HELMY, I., 1980. The contemporary land mammals of Egypt (including Sinai). Chicago: Field Museum of Natural History. New Series, no. 5.

PANEK, M., and BRESINKSI, W., 2002. Red fox Vulpes vulpes density and habitat use in a rural area of western Poland in the end of 1990s, compared with the turn of 1970s. Acta Theriologica, vol. 47, no. 4, pp. 433-442.

RESHAMWALA, H.S., SHROTRIYA, S., BORA, B., LYNGDOH, S., DIRZO, R. and HABIB, B., 2018. Anthropogenic food subsidies change the pattern of red fox diet and occurrence across Trans-Himalayas, India. Journal of Arid Environments, vol. 150, pp. 15-20. http:// dx.doi.org/10.1016/j.jaridenv.2017.12.011.

ROBERTS, T.J., 1997. The mammals of Pakistan (revised edition). Karachi: Oxford University Press, 525 p.

SHARMA, D.K., MALDONADO, J.E., JHALA, Y.V. and FLEISCHER, R.C., 2004. Ancient wolf lineages in India. Proceedings. Biological Sciences, vol. 271, suppl. 3, pp. S1-S4. http://dx.doi.org/10.1098/ rsbl.2003.0071. PMid:15101402.

SIDOROVICH, V.E., SIDOROVICH, A.A. and IZOTOVA, I.V., 2006. Variations in the diet and population density of the red fox Vulpes vulpes in the mixed woodlands of northern Belarus. Mammalian Biology, vol. 71, no. 2, pp. 74-89. http://dx.doi. org/10.1016/j.mambio.2005.12.001.

SOE, E., DAVISON, J., SULD, K., VALDMANN, H., LAURIMAA, L. and SAARMA, U., 2017. Europe-wide biogeographical patterns in the diet of an ecological and epidemiologically important meso-predator, the red fox Vulpes vulpes: a quantitative review. Mammal Review, vol. 47, no. 3, pp. 198-211. http://dx.doi. org/10.1111/mam.12092.

STATHAM, M.J., MURDOCH, J., JANECKA, J., AUBRY, K.B., EDWARDS, C.J., SOULSBURY, C.D., BERRY, O., WANG, Z., HARRISON, D., PEARCH, M., TOMSETT, L., CHUPASKO, J. and SACKS, B.N., 2014. Range-wide multilocus phylo-geography of the red fox reveals ancient continental divergence, minimal genomic exchange and distinct demographic histories. Molecular Ecology, vol. 23, no. 19, pp. 4813-4830. http://dx.doi.org/10.1111/mec.12898. PMid:25212210.

SZUMA, E., 2008. Evolutionary and climatic factors affecting tooth size in the red fox Vulpes vulpes in the Holartic. Acta Theriologica, vol. 53, no. 4, pp. 89-332.

WERHAHN, G., SENN, H., KADEN, J., JOSHI, J., BHATTARAI, S., KUSI, N., SILLERO-ZUBIRI, C. and MACDONALD, D.W., 2017. Phylogenetic evidence for the ancient Himalayan wolf: towards a clarification of its taxonomic status based on genetic sampling from western Nepal. Royal Society Open Science, vol. 4, no. 6, pp. 170186. http:// dx.doi.org/10.1098/rsos.170186. PMid:28680672.

WILLIAMS, J.B., MUNOZ-GARCIA, A., OSTROWSKI, S. and TIELEMAN, B.I., 2004. A phylogenetic analysis of basal metabolism, total evaporative water loss, and life-history among foxes from desert and mesic regions. Journal of Comparative Physiology. B, Biochemical, Systemic, and Environmental Physiology, vol. 174, no. 1, pp. 29-39. http://dx.doi.org/10.1007/s00360-0030386-0. PMid:14564467.

WILSON, V. and DOOKIA, S., 2019. Desert fox (Vulpes vulpes pusilla) a generalist or opportunistic specialist: insight into the feeding habit of Thar Desert of Rajasthan, India. Environment and Ecology, vol. 37, no. 4, pp. 1133-1139. 


\section{Supplementary Material}

Supplementary material accompanies this paper.

Supplementary Table S1. Samples included in the phylogenetic analysis with the ID number, geographic origin, and reference. There are red fox samples and one Corsac fox (Vulpes corsac) as an outgroup (NCBI ID = JF489127.1). KPK refers to the administrative province of Khyber Pakhtunkhwa in Pakistan.

This material is available as part of the online article from https://www.scielo.br/j/BJB 